\title{
Large scale patterns of genetic differentiation at enzyme loci in the land snails Cepaea nemoralis and Cepaea hortensis
}

\author{
H. Ochman,* \\ J. S. Jones $\dagger$ and \\ R. K. Selandert
}

\author{
* Department of Biochemistry, University of \\ California, Berkeley CA 94720 , U.S.A. \\ $\dagger$ Department of Genetics and Biometry, University \\ College London, London NW1 $2 \mathrm{HE}$ \\ $\mp$ Department of Biology, University of Rochester, \\ Rochester, NY 14627, U.S.A.
}

Samples of 231 populations of the land snails Cepaea nemoralis and $\boldsymbol{C}$. hortensis from Britain, France, Switzerland and Spain were analysed for genetic polymorphism in six enzyme systems. These sibling species show similar levels of variation detected by electrophoresis, and have a generally similar degree of local divergence over homologous enzyme loci. As well as extensive local and regional differentiation, both species show large-scale changes in allele frequency across Europe. In $C$. hortensis there is a continuous gradient in allele frequency from northern Britain to northern Spain, while in $C$. nemoralis north-south clines on the continent of Europe are reversed in direction in Britain. There are few obvious correlations of allele frequency change at single loci with components of the environment. Patterns of allele frequency variation in 24 sympatric populations of the two species are generally independent of each other, although there is a positive association of the frequencies of alleles at a leucine aminopeptidase locus in the two species. The statistical significance of this association depends on a single locality, and there is little indication of shared patterns of allele frequency change which might reflect a common response to natural selection. In addition, there is no evidence that the extensive geographical change in $C$. nemoralis and $C$. hortensis is a precursor of speciation.

\section{INTRODUCTION}

The land snails Cepaea nemoralis and C. hortensis are sibling species whose conspicuous shell polymorphisms have been the subject of extensive ecological and genetic research (Jones et al., 1977). The frequencies of these characters respond to various agents of natural selection (e.g., Cain and Sheppard, 1954; Arnold, 1968) but analysis of their associations with the environment is complicated by the fact that other evolutionary forces, such as migration and fluctuations in population size, can also influence the distribution of genes ( Nei, 1975; Selander, 1975).

In many places, both species of Cepaea show patterns of extreme local differentiation ("area effects"; Cain and Currey, 1963), in which certain shell morphs predominate over large and ecologically diverse regions separated by steep clines from adjacent areas with quite different morph frequency. This microgeographic structuring exists

$\uparrow$ Address for reprints. within a context of large-scale gradients of allele frequency for shell characters across Europe, some of which are associated with climate (Jones et al, 1977). Some populations of C. nemoralis also show marked geographical differentiation in allele frequencies at structural gene loci detected by enzyme electrophoresis (Johnson, 1979; Jones et al., 1980; Caugant et al., 1982; Valdez-Forsans, 1983). In the Pyrenees, in particular, enzyme polymorphisms show patterns of strong local divergence which are concordant over loci (Ochman et al., 1983). These regions of relative genetic unifor. mity (or "molecular area effects") are analogous to area effects for shell characters but exist on a much larger scale.

There are several models for the origin of area effects, including microclimatic selection (Cain and Currey, 1963; Arnold, 1968), local coadaptation (Clarke, 1966; Slatkin, 1982) and allopatric divergence followed by secondary contact (Goodhart, 1962; Cameron et al., 1980). In the absence of evidence for selection, we have suggested that molecular area effects arise from 
stochastic factors related to founder effects and genetic drift in populations isolated by Pyrenean glaciations.

Comparisons of patterns of geographic variation of shell polymorphism in the two species of Cepaea have provided some useful insights into their evolution (Clarke, 1962). It has often been suggested that parallel variation at homologous enzyme loci can be taken as evidence for natural selection even when the causative agents are not known (Clarke, 1975; Borowsky, 1977; Varvio-Aho and Pamilo, 1982), and this approach has been used to infer the action of selection on enzyme loci in sympatric species of fish (Johnson, 1974), butterflies (McKechnie et al., 1975), estuarine molluscs (Koehn and Mitton, 1972; Newkirk and Doyle, 1979), field crickets (Harrison, 1977), grasshoppers (Gill, 1981) and Drosophila (Borowsky, 1977; Anderson and Oakeshott, 1984).

Here we examine patterns of geographic differentiation at enzyme loci in Cepaea nemoralis and $C$. hortensis across western Europe to determine the scale of organization of enzyme polymorphism in these species. This may make it poss ible to identify common selective or demographic

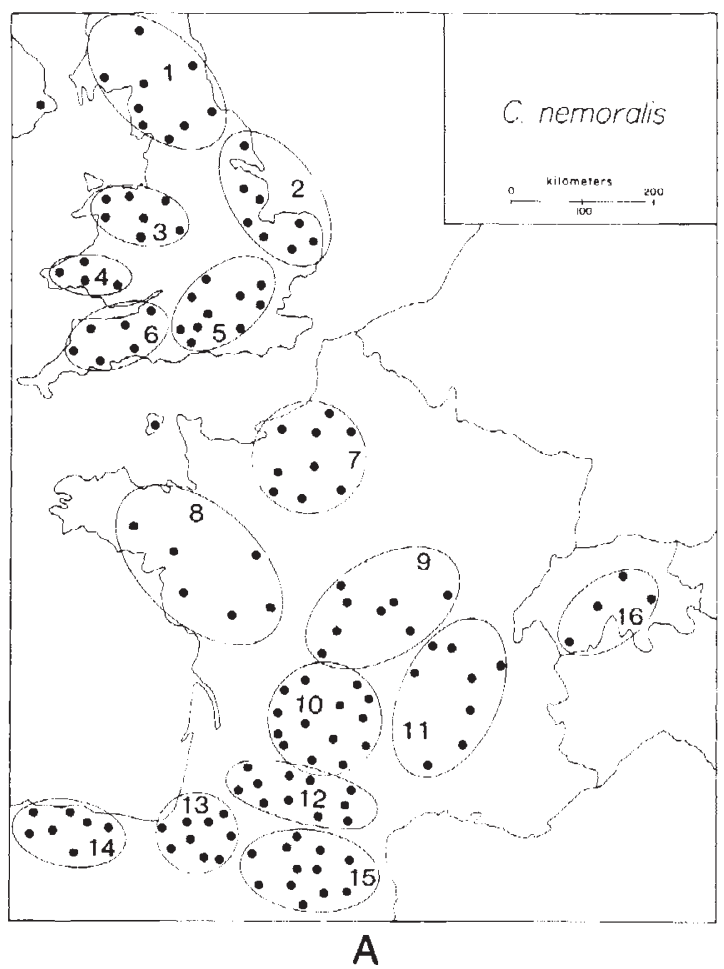

forces which act upon them. As both species are highly polymorphic and share alleles at many enzyme loci (Levan and Fredga, 1972; Johnson, 1979; Selander and Ochman, 1983) we pay particular attention to correlations among enzyme loci in sympatric populations of these snails which might give evidence on the action of selection.

\section{MATERIALS AND METHODS}

One hundred and thirty four populations of $C$. nemoralis and 92 populations of $C$. hortensis were sampled in Britain and Europe between 1978 and 1982 (fig. 1). The collections were separated by at least $25 \mathrm{~km}$ and were taken from a wide range of habitats. The mean sample size is approximately 30 , and all snails collected were scored for shell characters. Ten individuals were taken from each sample for enzyme electrophoresis (Selander et al., 1971). Six enzyme systems known to be polymorphic in nemoralis were assayed in each species: phosphoglucose isomerase (Pgi), indophenol oxidase (Ipo), leucine aminopeptidase (Lap), malate dehydrogenase $(M d h)$, phosphoglucomutase

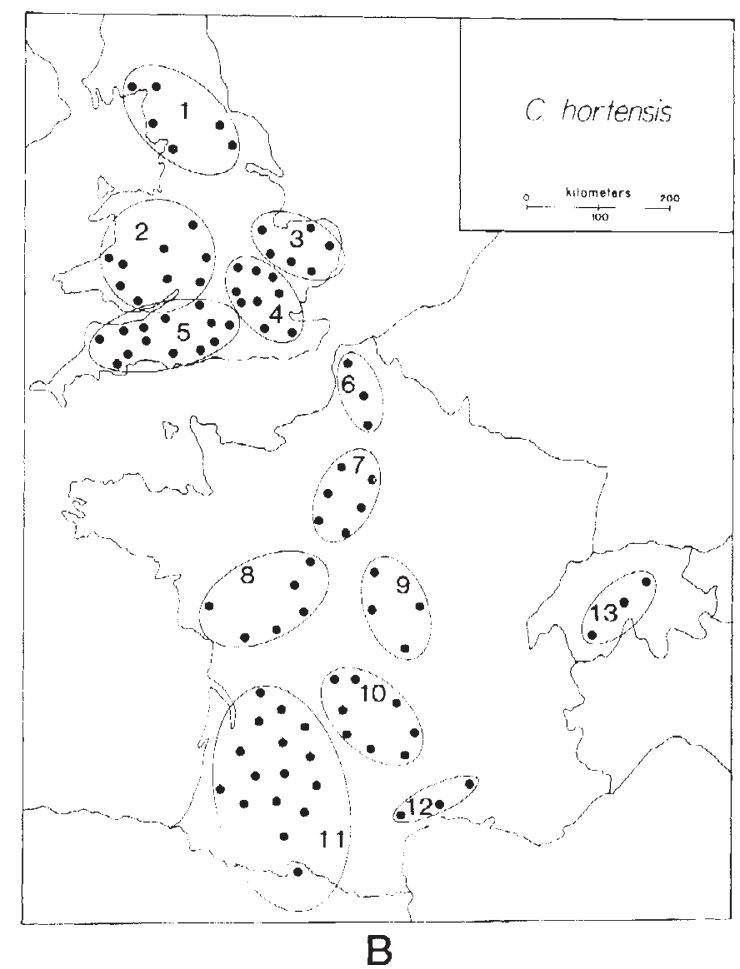

Figure 1 Collection localities for Cepaea nemoralis and C. hortensis. Ellipses define geographic regions used in the analysis of population structure. 
$(P g m)$ and isocitrate dehydrogenase (Idh). This produced eight putative polymorphic loci in hortensis (which shows variation in at least some populations at two Lap and two Idh loci) and seven in nemoralis (which has only one polymorphic Idh locus). Mendelian inheritance of allozymes at many of these loci has been established by Johnson (1979). Six of them (Pgi, Ipo, Lap-2, Mdh, $P g m$, and $I d h-1)$ were polymorphic in most populations and were used to establish patterns of geographic structure; the other two are only sporadically variable and were utilised only in comparisons of interspecific patterns of genetic change.

Hierarchical $F$-statistics (Wright, 1978) were used to estimate standardised variances in allele frequency at several levels of population structure: $F_{\mathrm{DR}}$, among demes (sampling sites) within regions (16 regions for C. nemoralis and 13 for C. hortensis, as indicated by ellipses in fig. 1); $F_{\mathrm{RS}}$, among regions within subdivisions (Britain and continental Europe); and $F_{\mathrm{ST}}$, between subdivisions within the total area sampled. All estimates were adjusted for sampling error. A principal components analysis (Sneath and Sokal, 1973) was used to examine spatial patterns of association of variables among loci. Large-scale patterns of allele frequency were

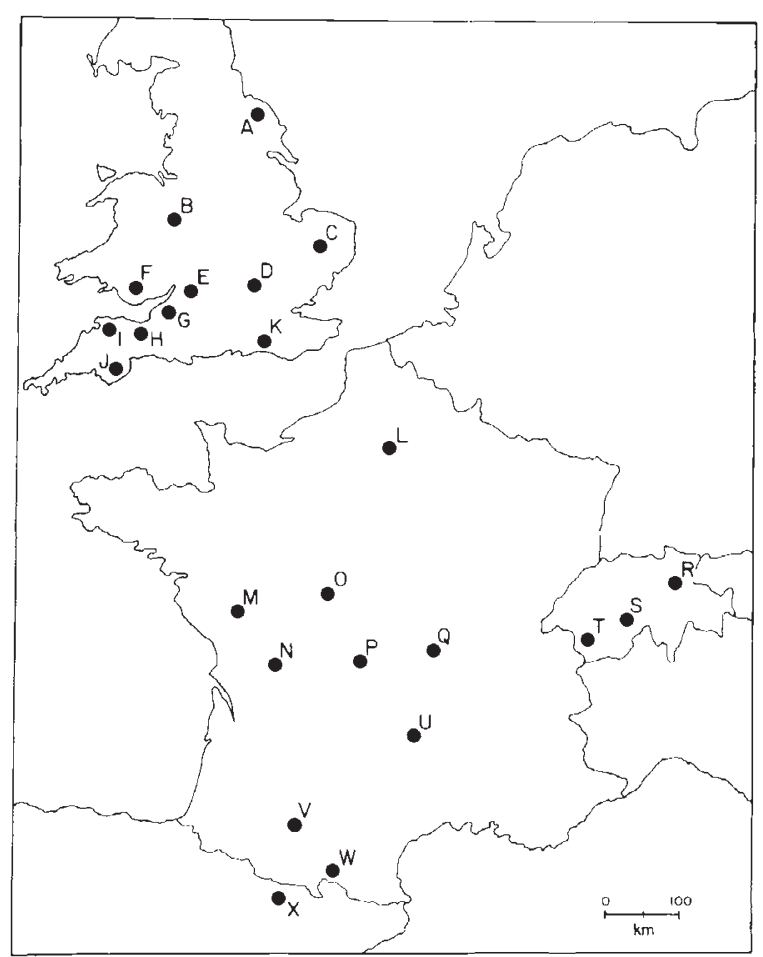

Figure 2 Locations of sympatric populations of $C$. nemoralis and $C$. hortensis. examined utilising maps similar to those used by Menozzi et al. (1978) and Piazza et al. (1981a,b) for human populations. In these maps, factor scores are interpolated at the nodes of $65 \mathrm{~km}$ square grid over the whole area sampled. At each node, the unweighted average of factor scores (scaled from zero to one) within a circle with a radius equal to the distance between each node is taken, and the range of the averaged factor scores divided into uniform intervals which can be represented as different intensities of shading on a map.

Parallel variation in allele frequencies at homologous loci were analysed in sympatric populations of nemoralis and hortensis from 24 sites in Britain, France, Switzerland and Spain (fig. 2). Only those enzyme loci which were polymorphic in more than five of these populations were used in the analysis. For each locus, arcsine-transformed frequencies of the most common alleles in nemoralis were plotted against those in hortensis from the same place. Not all samples could be used in the analysis of Lap-2 because of the presence of a null allele in some populations.

\section{RESULTS}

\section{Analysis of genetic diversity and variance}

Allele frequencies at enzyme loci and at those controlling shell characters are listed in Ochman et al. (1986). We will not consider shell polymorphism in detail here, as this is the subject of a separate study based on much more extensive information. Although $C$. hortensis is generally less polymorphic for shell characters than is $C$. nemoralis, genetic diversity over the polymorphic enzyme loci studied was the same in the two species, with a mean heterozygosity of 0.34 for each.

Geographic variation in allele frequency at three levels of population structure is summarised in table 1 . The relatively high scores for $F_{\mathrm{DR}}$ indicate that both species show large components of components of diversity within geographic regions. Although there is no apparent relationship between values of this statistic at homologous enzyme loci in the two species $(r=-0 \cdot 32)$, the mean $F_{\mathrm{DR}}$ over all enzyme loci is similar in the two species $\left(F_{\mathrm{DR}}\right.$, nemoralis $=0 \cdot 187$; hortensis $=$ $0 \cdot 197)$.

Average regional differentiation within subdivisions $\left(F_{\mathrm{RS}}\right)$ for enzyme loci in nemoralis $(0 \cdot 132)$ is about twice that estimated for hortensis $(0.06)$. This difference might arise in part because nemoralis was sampled over a larger area than was hortensis, and includes samples from the Pyrenees, 
where there are areas of marked differentiation at enzyme loci (Ochman et al., 1983). If the Pyrenees are omitted from the analysis, $F_{\mathrm{RS}}$ for nemoralis is reduced to 0.096. However, when only British samples of the two species are considered, regional differentiation of nemoralis is about four times greater than is that for hortensis. C. nemoralis does appear to be more regionally subdivided than is its sibling species.

Mean standardised variances in allele frequencies between samples from Britain and those from the European continent $\left(F_{\mathrm{ST}}\right)$ are, at 0.02 , the same in both species. This component of geographical variance is small compared with that at the demic or regional level.

\section{Patterns of differentiation at enzyme loci}

To study the concordance of patterns of geographic variation at all loci simultaneously, we subjected arcsine-transformed allele frequencies at the six enzyme loci to a principal components analysis. Figs. 3 and 4 show component scores, scaled from zero to one, on the first two principal axes for each collection locality. Much of the genetic variation

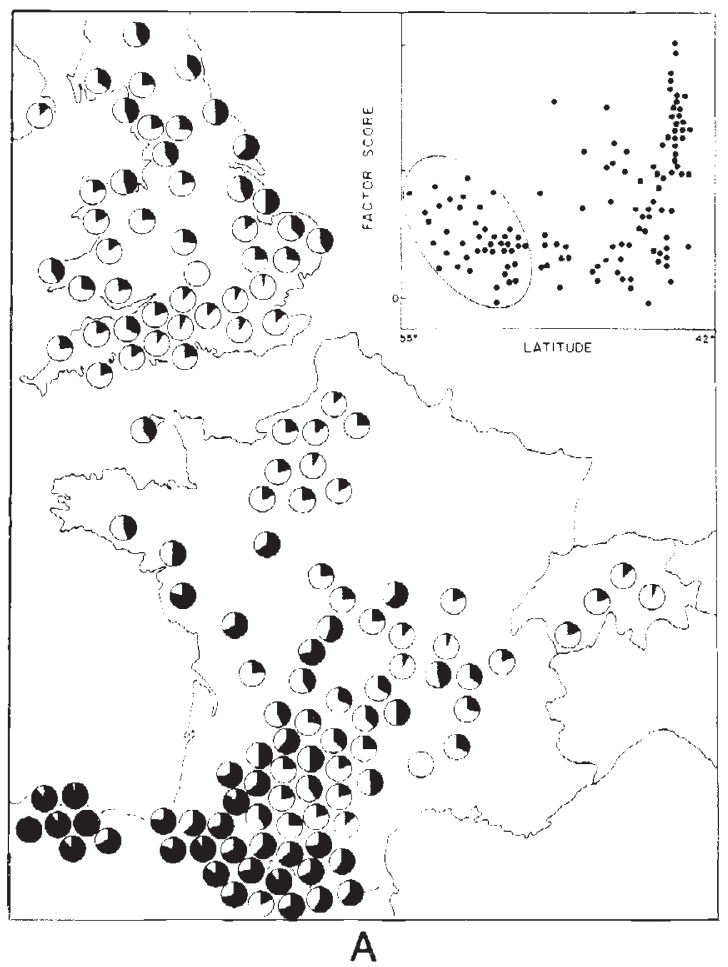

at enzyme loci in these populations is associated with geographic position, and the scores for factors 1 and 3 in nemoralis and factors 1 and 2 in hortensis show significant north-south gradients (table 2).

Although such correlations of factor score with latitude could be interpreted as evidence for climatic selection, closer examination of the spatial patterns described here suggests that this is not likely to be the case, as there are marked differences in the patterns of spatial variation at particular loci and for principal component scores within each species. In hortensis there is a consistent change in allele frequencies at loci correlated with the first principal axis which extends across Britain and Europe (fig. 3 and inset). Despite an overall correlation with latitude, the situation in nemoralis is rather different; British and European samples show trends in opposite directions, with factor scores increasing as to the North in Britain and to the South in Europe south of the English Channel (inset to fig. 3(a): points within the ellipse represent the 44 British samples; $r=-0.459, p<0.001$ for these samples).

Two of the three loci (Pgm and Lap) with high loadings on the first principal component are the

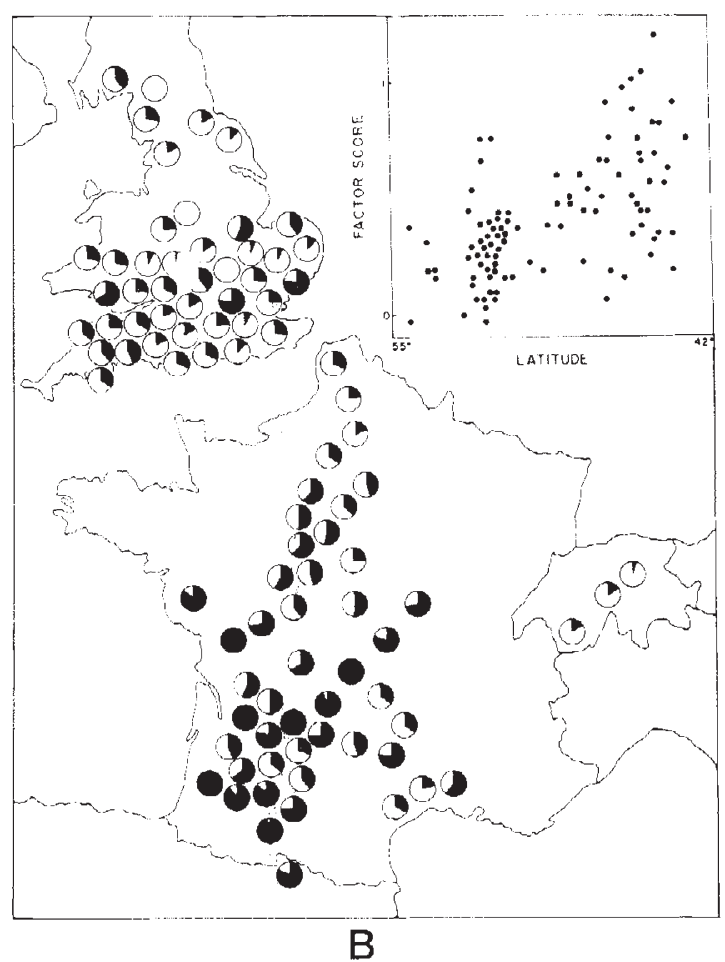

Figure 3 Scores, scaled from zero to one, for Factor 1 (shaded), based on allele frequencies at six polymorphic enzyme loci in $C$. nemoralis (a) and $C$. hortensis (b). Insets show the relationship between factor score and latitude. Points within the ellipse in fig. 3(a) represent collections from Britain. 

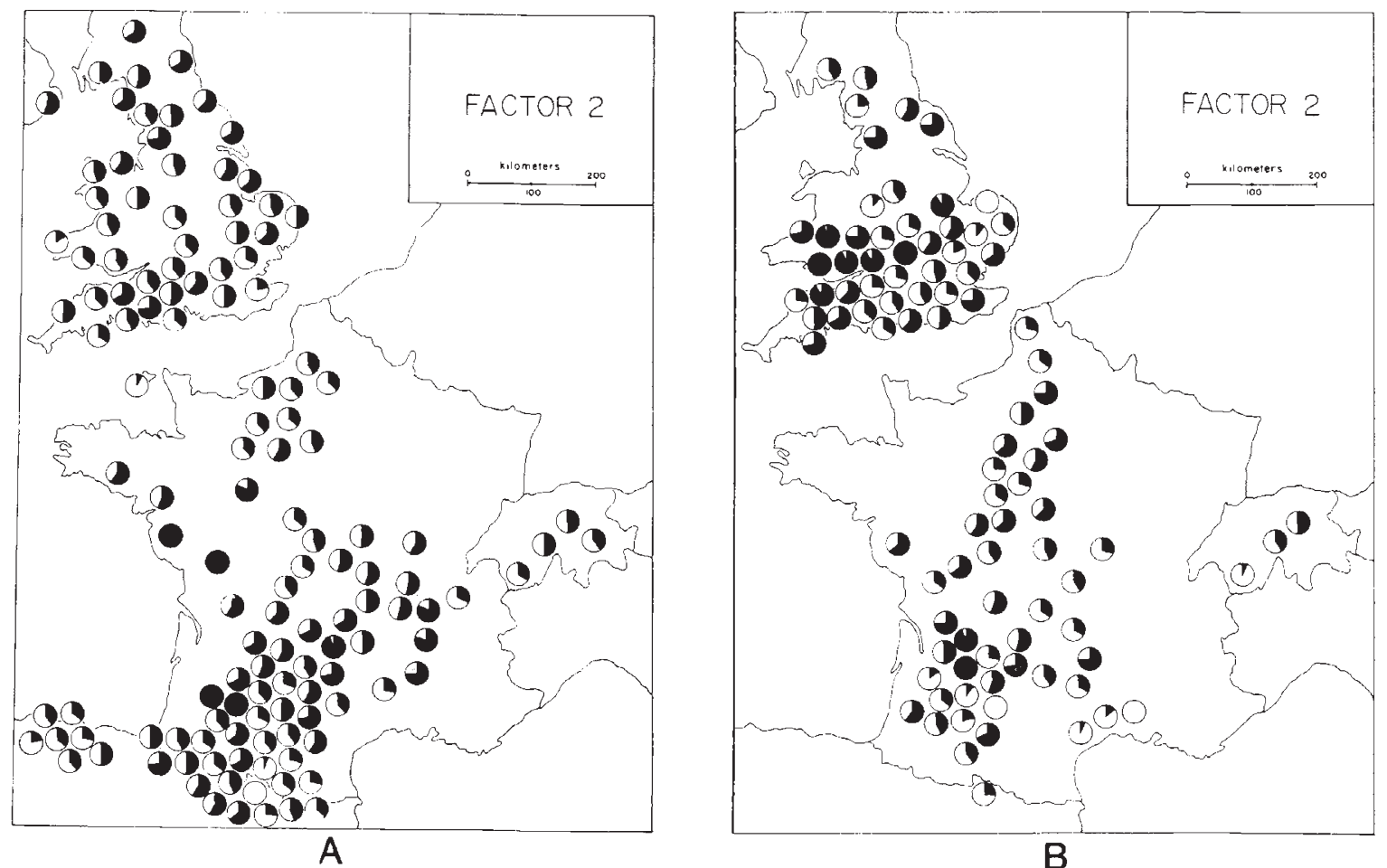

Figure 4 Scores, scaled from zero to one, for Factor 2 (shaded) in C. nemoralis (a) and C. hortensis (b).

same in the two species. The probability of this occurring by chance is $0 \cdot 3$.

The clines in allele frequency (as reflected by scores on the first principal component) are shown in figs. 5(a) and 5(b) which use a "running average" to eliminate much of the local variation seen in the previous figures. North-south clines are still apparent in British populations of both species, but the major patterns of variation which emerge in Europe are clines from east to west, with eastern populations being more similar to those in Britain for both nemoralis and hortensis.

\section{Correlations among loci in sympatric populations}

At 24 localities, both species of Cepaea were collected. Only 3 of 40 comparisons of allele frequencies in nemoralis and hortensis gave statistically significant correlations (fig. 6). One of these involved comparisons of indistinguishable electromorphs at the Lap-1 locus. In general, northern populations of both species are monomorphic at this locus, but there is no clear-cut gradient in the degree of polymorphism. However, Lap-1 is not a very polymorphic locus, and by eliminating the

Table 1 Estimates of variance from hierarchical F-statistics analysis for Cepaea nemoralis and $C$. hortensis in western Europe

\begin{tabular}{lcccccc}
\hline & \multicolumn{3}{c}{ Cepaea nemoralis* } & \multicolumn{3}{c}{ Cepaea hortensis $\dagger$} \\
Locus & $F_{\mathrm{DR}}$ & $F_{\mathrm{RS}}$ & $F_{\mathrm{ST}}$ & $F_{\mathrm{DR}}$ & $F_{\mathrm{RS}}$ & $F_{\mathrm{ST}}$ \\
\hline Pgi & 0.264 & 0.222 & 0 & 0.163 & 0.016 & 0.016 \\
Ipo & 0.176 & 0.089 & 0.049 & 0.203 & 0.091 & 0.040 \\
Lap & 0.186 & 0.070 & 0.008 & 0.214 & 0.139 & 0.040 \\
Mdh & 0.231 & 0.152 & 0.016 & 0.155 & 0.022 & 0 \\
$P g m$ & 0.141 & 0.197 & 0.036 & 0.252 & 0.056 & 0.016 \\
Idh & 0.120 & 0.064 & 0.088 & 0.197 & 0.039 & 0.012 \\
$\overline{\mathrm{X}}_{\text {(enzyme loci) }}$ & 0.187 & 0.132 & 0.020 & 0.197 & 0.060 & 0.020 \\
\hline
\end{tabular}

* 134 demes in 16 regions in two subdivisions

$\dagger 92$ demes in 13 regions in two subdivisions 


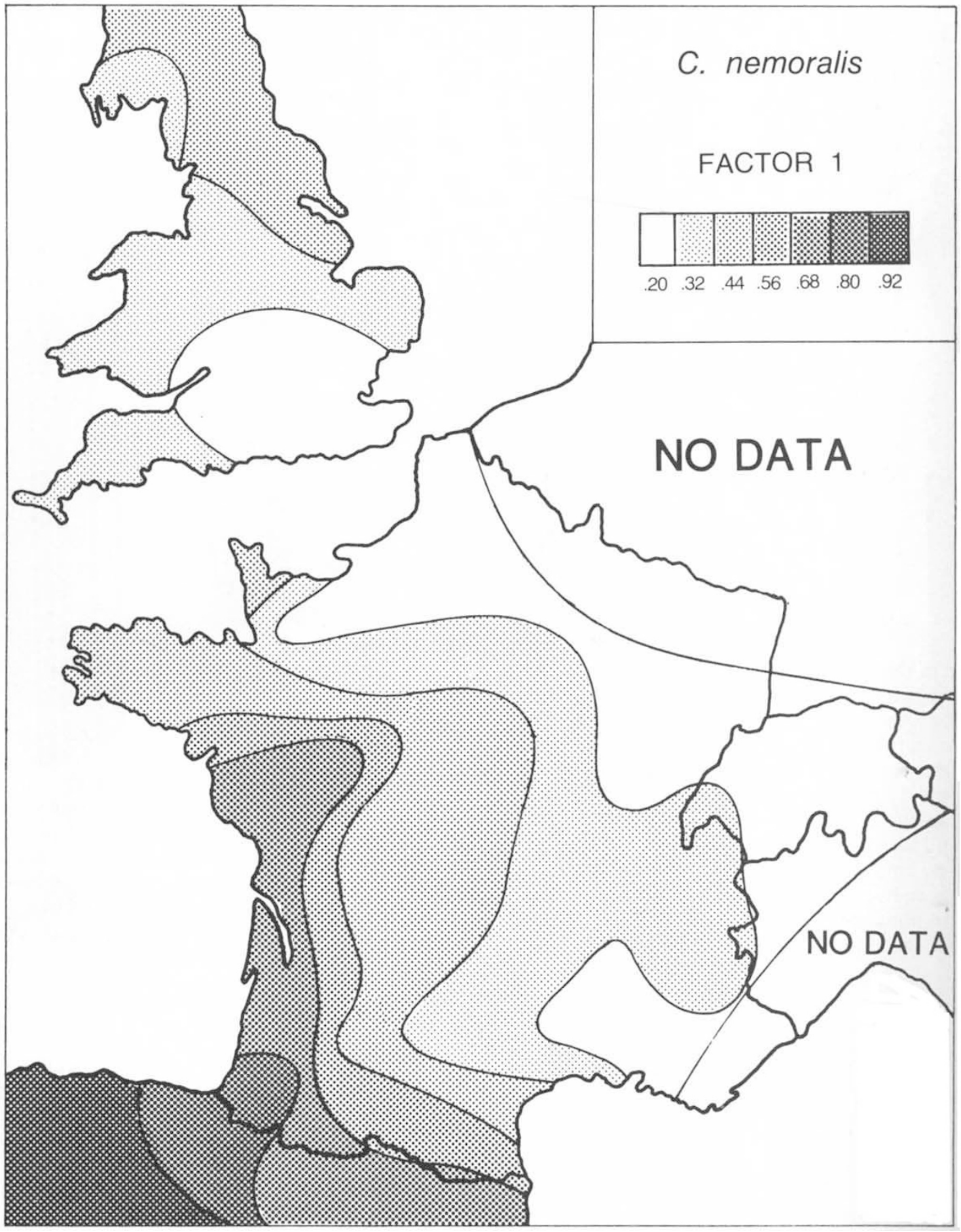

Figure 5 First principal component of allele frequencies at six polymorphic enzyme loci, with intensity of shading indicating the magnitude of factor scores (see text). 


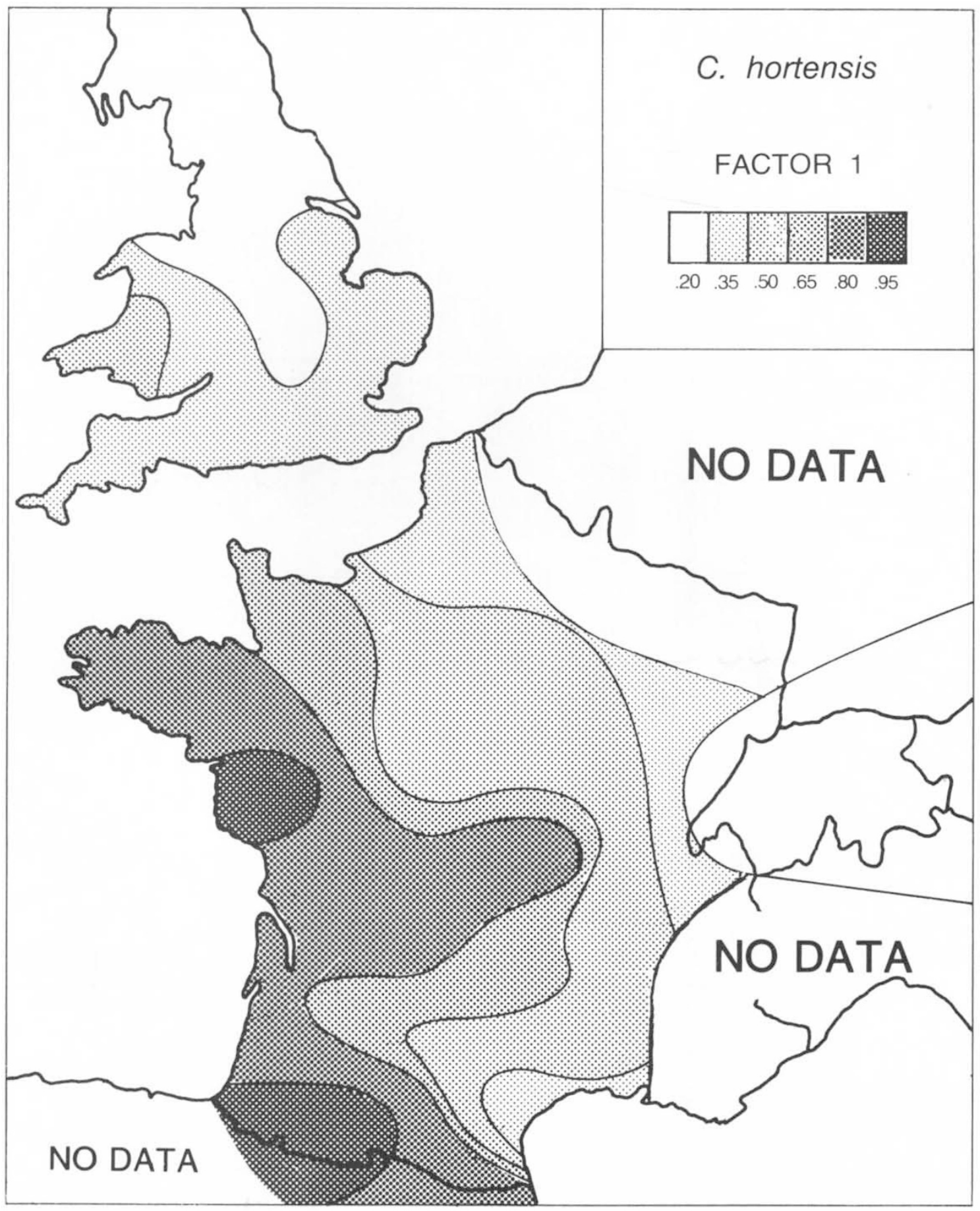


Table 2 Summary of principal components analysis

\begin{tabular}{|c|c|c|}
\hline & $\begin{array}{l}\text { Cepaea nemoralis } \\
(n=132)\end{array}$ & $\begin{array}{l}\text { Cepaea hortensis } \\
(n=94)\end{array}$ \\
\hline \multicolumn{3}{|l|}{ Factor 1} \\
\hline Loci correlated with factor* & Pgi, Pgm, Lap & Ipo, Lap, Pgm \\
\hline Variance explained & $25 \cdot 1 \%$ & $20 \cdot 8 \%$ \\
\hline Correlation with latitude & $r=0.481(p<0.001)$ & $r=0.546(p<0.001)$ \\
\hline \multicolumn{3}{|l|}{ Factor 2} \\
\hline Loci correlated with factor & Idh, Ipo, Lap & Pgi, Idh \\
\hline Variance explained & $17 \cdot 0 \%$ & $14 \cdot 4 \%$ \\
\hline Correlation with latitude & $r=0.022(p<0.5)$ & $r=0.235(p<0.05)$ \\
\hline \multicolumn{3}{|l|}{ Factor 3} \\
\hline Loci correlated with factor & $M d h, P g m$ & $M d h, P g i$ \\
\hline Variance explained & $8.7 \%$ & $11 \cdot 7 \%$ \\
\hline Correlation with latitude & $r=-0.383(p<0.001)$ & $r=-0.058(p<0.5)$ \\
\hline
\end{tabular}

* Includes loci with loadings greater than \pm 0.5 for one or more alleles; loci listed in order of decreasing factor loadings
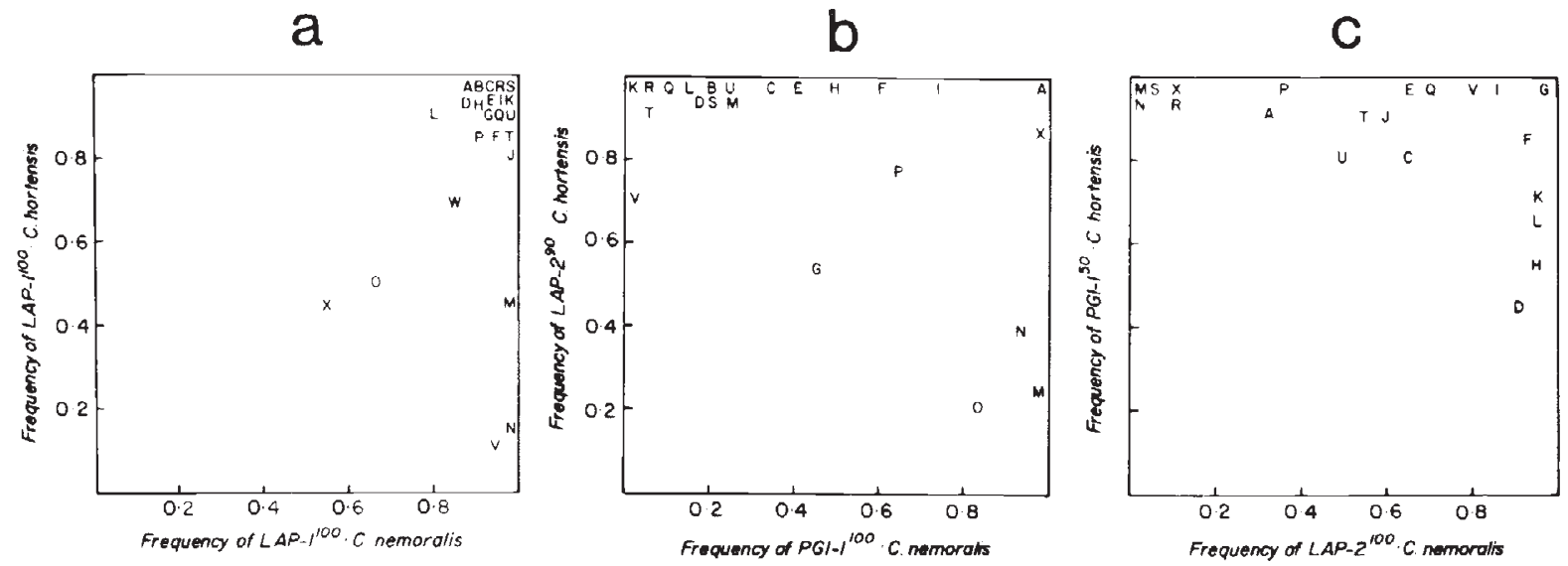

\begin{tabular}{|c|c|c|c|c|}
\hline & \multicolumn{2}{|c|}{ Number of } & \multirow[b]{2}{*}{ Loci involved } & \multirow[b]{2}{*}{$\begin{array}{l}\text { Level of } \\
\text { significance }\end{array}$} \\
\hline Type of comparison & Comparisons & $\begin{array}{l}\text { Significant } \\
\text { correldtions }\end{array}$ & & \\
\hline Homologous enzyme loci & 5 & 1 & Lap $-1_{\text {nem }}-$ Lap- $1_{\text {nort }}$ & $<.05$ \\
\hline \multirow[t]{2}{*}{ Non-homologous enzyne loci } & 35 & 2 & $P g i-1_{\text {neml }}-$ Lap $-2_{\text {hort }}$ & $<.01$ \\
\hline & & & Lap-2 $2_{\text {nem }}-P g i-1_{\text {nort }}$ & $<.05$ \\
\hline
\end{tabular}

Figure 6 Plots of allele frequencies in $C$. nemoralis and $C$. hortensis which have significant $(p<0 \cdot 05)$ correlation coefficients. Letters indicate the collection localities shown on fig. 2. The table includes all comparisons which reach statistical significance. 
most variable collection $(X)$ the correlation coefficient between the two species drops to 0.385 and is no longer significant $(0 \cdot 10>p>0 \cdot 05)$. The two significant correlations among the 35 comparisons of non-homologous enzymes involve the same loci in each species (figs. 6(b) and 6(c)). However, for neither Pgi nor Lap-2 considered alone is there a significant parallel variation between species (for Pgi $r=0 \cdot 225, \mathrm{df}=23$; and for Lap $r=0 \cdot 264$, $\mathrm{df}=19$ ), so that these correlations are likely to arise from chance alone.

\section{DISCUSSION}

Much of the genetic differentiation at enzyme loci in Cepaea is in the form of clines which extend across Britain and Europe. These are superimposed on patterns of extensive local differentiation at enzyme loci which produce marked genetic subdivision in some places. For example, populations of nemoralis in the Pyrenees (Caugant et al., 1982; Ochman et al., 1983) have differentiated to a degree which is equivalent to that found among races, subspecies or even species in other genera ( Nei, 1975; Avise and Aquadro, 1982). On the European scale there is also considerable genetic differentiation at each of the loci studied here. In $C$. nemoralis different populations are fixed for alternative alleles at four of the six loci, and in $C$. hortensis two of these loci are monomorphic for different variants in geographically separated populations. This pattern of local geographic variation within a context of large-scale clines is analogous to the patterning of many of the loci controlling shell polymorphism in both species of Cepaea (Jones et al., 1977).

$C$. nemoralis and $C$. hortensis differ in the direction of geographic change in allele frequency and in the alleles involved in clinal change. In nemoralis, populations with relatively high frequencies of particular alleles at $P g i, P g m$ and Lap (and to some extent $M d h$ and Ipo, which have loadings of 0.45 and 0.44 on principal component I) occur near the English Channel and decrease in frequency to the north and south of this. In contrast, hortensis shows continuous gradients in allele frequency at loci correlated with Factor I (Ipo, Lap, Pgm) from northern England to Spain.

Geographical patterns of gene frequency within species are not very helpful in determining the relative importance of selection and drift. Although there is little consistency in the genetic patterning of these species on a small scale, there are some rather striking large-scale geographical patterns of some principal components which could in principle be ascribed to an inter-regional selective differential partly obscured by interdemic drift. However, no single selective force can easily be invoked to account for the patterns of genetic differentiation found within either of the species studied here. In nemoralis, latitudinal changes in allele frequency in British populations are reversed in France and Spain. Although there are some consistent trends in hortensis, these usually involve different loci from those which show large-scale patterning in nemoralis and it is not easy to see why any geographic trend in selection should act in only one of a pair of sibling species. Several detailed surveys of allele frequency distribution at enzyme loci in $C$. nemoralis give no evidence of association of genetic structuring with identifiable components of the environment (Johnson, 1979; Jones et al., 1980; Ochman et al., 1983).

It is in principle possible to detect the action of selection by identifying correlated patterns of geographic change in sympatric populations of closely related species. Comparison of allele frequencies in nemoralis and hortensis at the 24 sites in which both species were present gave three statistically significant correlations. The correlation between electromorphs at the Lap-1 locus depends on a single locality, and is not compelling evidence of a common agent of natural selection. There is, however, some evidence at selection acting at an Lap locus in the mussel Mytilus (Koehn et al., 1976, 1980) and Foltz et al. (1982) describe an unusually high level of geographic differentiation for Lap in four species of slugs. The reciprocal correlation which we have found between Pgi and Lap-2 in C. nemoralis and $C$. hortensis, although significant, is somewhat enigmatic. As these loci are not functionally or structurally related it is difficult to suggest a meaningful explanation for this association.

Correlated patterns of geographic change in closely related species have often been claimed to result from the action of selection. There are two potential problems in evaluating such claims. First, there may be bias as negative results are rarely reported. Second, there is sometimes a problem of multiple testing; as such studies usually involve a considerable number of loci, allele frequency associations among loci will often arise by chance (Varvio-Aho and Pamilo, 1982). For example, if all the observed variation were neutral, the probability of a single significant result in as few as 10 interspecies comparison is 0.4 by chance alone, with the probability increasing as a function of the 
number of loci $(n)$ examined by $1-0 \cdot 95^{n}$ (Tukey, 1977). There is hence a danger of erroneously accepting the action of selection unless all interspecific comparisons of allele frequency are considered during such analyses.

Although there are some parallels in the patterns of large scale genetic change at enzyme loci in the two species studied here these are not strong evidence for the action of selection; such patterns are equally likely to arise from a shared demographic history. Only shared mosaic patterns of parallel change can confidently be ascribed to selection, and no information of this kind is yet available for enzyme loci in Cepaea. The scale and pattern of genetic differentiation at the various loci which he have studied shows a general similarity within each of the two species. Such similarities among loci of very different function are perhaps more likely to result from a shared history of population subdivision (and to a common pattern of genetic change arising from drift and migration which may influence many loci simultaneously) than to the joint action of selection on a diverse group of enzyme loci. The probable importance of random change in controlling the distribution of alleles at enzyme loci in Cepaea is supported by the extensive local differentiation-sufficient to lead to the fixation of alternative alleles in populations separated by a few kilometres-which exists in Pyrenean populations of $C$. nemoralis. These extensive changes, which are concordant over loci, are not easy to relate to an obvious ecological factor, and may have arisen from population bottlenecks occurring during periods of glaciation. Although the scale of sampling used here is too coarse to reveal details of population structure, concordant local differences as extensive as those found in the Pyrenees do not appear to be a general feature of the genetic structure of either species. However, both nemoralis and hortensis show relatively high population differentiation in the region north of the Pyrenees, perhaps because of a common demography during recent glaciations.

Geographic patterning of enzyme polymorphism in both species of Cepaea is most manifest among demes within geographic regions. $F_{\mathrm{DR}}$ values (which reflect this) are 0.187 for nemoralis and 0.197 for hortensis. These figures are close to the mean $F_{D R}$ of 0.198 for a number of enzyme loci in populations of the recently introduced snail Helix aspersa in regions of California of about the same area as that of the present survey (Selander and Whittam, 1983). The rapid spread and extensive population subdivision known to exist in $H$. aspersa suggests that most of its spatial variation arises from drift, a view supported by the similarity of variance estimates over its enzyme loci. The extent of genetic subdivision is less homogeneous over loci in Cepaea than in Californian Helix, perhaps because Cepaea populations have undergone more complex patterns of local fission and fusion during their evolutionary history. The local distribution and abundance of $C$. nemoralis in southern England has undergone considerable fluctuations over periods of a few years (Williamson et al., 1977; Cameron et al., 1980), and subfossil samples show that the ranges of nemoralis and hortensis have altered greatly since the most recent European glaciations (Cain, 1971). The demographic history of these snails supports the view that genetic changes at enzyme loci reflect the action of genetic drift, but the action of as yet unidentified local forces of selection cannot be excluded.

The extent of such genetic changes within each of the species studied here is far greater than that which exists among many pairs of sibling species in other groups. Indeed, within nemoralis or hortensis it is possible to identify populations which differ from each other at enzyme loci to an extent considerably greater than the mean genetic differences between the two species. However, in spite of their extensive genetic divergence, there is little evidence of reproductive isolation among $C$. nemoralis collected from Britain, France, Spain and North America (Cain et al., 1960; Johnson et al., 1984) and no indication that its populations are in the early stage of speciation. The existence of extensive genetic change at the molecular level in freely interbreeding populations of Cepaea provides little support for the view (White, 1978a, $b$ ) that new species are likely to arise as a product of genetic differentiation in continuous populations of organisms with low mobility.

Acknowledgements We thank Drs S. Borfield, L. R. Noble, P. J. Slepokura and D. W. Young for assistance in the field. This research was supported by grants from the National Institutes of Health to R.K.S. and from the Royal Society and Natural Environment Research Council to J.S.J.

\section{REFERENCES}

ANDERSON, P. R. AND OAKEShort, J. G, 1984. Parallel geographic patterns of allozyme variation in two sibling Drosophila species. Nature, 308, 729-731.

ARNOLD, R. W. 1968. Studies on Cepaea. VII. Climatic selection in Cepaea nemoralis (L.) in the Pyrenees. Phil. Trans. Roy. Soc. Lond., B 253, 549-593.

AVISE, J. C. AND AQUADRO, C. F. 1982. A comparative survey of genetic distances among the vertebrates: patterns and correlations. Evol. Biol., 15, 151-186. 
BOROWSKY, R. 1977. Detection of the effects of selection on protein polymorphisms by means of a distance analysis. Evolution, 31, 341-346.

CAIN, A. J. 1971. Colour and banding morphs in subfossil populations of the snail Cepaea. Creed, R., (ed.) In Ecological Genetics and Evolution, Blackwell Scientific Publications, Oxford, pp. 65-92.

CAIN. A. J. AND CURREY, J. D. 1963. Area effects in Cepaea. Phil. Trans. Roy. Soc. Lond., B 246, 1-81.

CAIN, A. J., KING, J. M. B. AND SHEPPARD, P. M. 1960. New data on the genetics of polymorphism in the snail Cepaea nemoralis L. Genetics, 45, 393-411.

CAIN, A. J. AND SHEPPARD, P. M. 1954. Natural selection in Cepaea. Genetics, 39, 89-116.

CAMERON, R. A. D., CARTER, M. A. AND PALLES-CLARKE, M. A. 1980. Cepaea on Salisbury Plain: patterns of variation, landscape history and habitat stability. Biol. J. Linn. Soc., 14, 335-358.

CAugANT, D. A., SElander, R. K. AND JONES, J. S. 1982. Geographic structuring of molecular and morphological polymorphisms in Pyrenean populations of the snail Cepaea nemoralis. Genetica, 57, 177-191.

CLARKE, B. C. 1962 . Natural selection in mixed populations of two polymorphic snails. Heredity, 17, 319-345.

Clarke, B. 1966. The evolution of morph-ratio clines. Amer. Natur., 100, 389-402.

CLARKE, B. 1975. The contribution of ecological genetics to evolutionary theory: detecting the effects of natural selection on particular polymorphic loci. Genetics, 79, 101-113 (suppl.).

FOLTZ, D. W., OCHMAN, H., JONES, J. S., EVANGEliSTI, S. M. AND SELANDER, R. K. 1982. Genetic population structure and breeding systems in arionid slugs (Mollusca: Pulmonata). Biol. J. Linn. Soc., 17, 225-241.

GILL, P. 1981. Allozyme variation in sympatric populations of British grasshoppers-evidence of natural selection. Biol. J. Linn. Soc. Lond., 16, 83-91.

GOODHART, C. B. 1962. Variation in a colony of the snail Cepaea nemoralis (L.). J. Anim. Ecol., 31, 207-237.

HARRISON, R. H. 1977. Parallel variation at an enzyme locus in sibling species of field crickets. Nature, 266, 168-170.

JOHNSON, M. S. 1974. Comparative geographic variation in Menidia. Evolution 28, 607-618.

JOHNSON, M. S. 1979. Inheritance and geographic variance of allozymes in Cepaea nemoralis. Heredity, 43, 137-141.

JOHNSON, M. S., STINE, O.C. AND MURRAY, J. 1984. Reproductive compatibility despite large-scale genetic divergence in Cepaea nemoralis Heredity, 53, 655-666.

JONES, J. S. LEITH, B. H. AND RAWLINGS, P. 1977. Polymorphism in Cepaea: a problem with too many solutions? Ann. Rev. Ecol. Syst., 8, 109-143.

JONES, J. S., SIELANDER, R. K. AND SCHNELL, G. D. 1980. Patterns of morphological and molecular polymorphism in the land snail Cepaea nemoralis. Biol. J. Linn. Soc. Lond., $14,359-387$.

KOEHN, R. K. AND MITTON, J. B. 1972. Population genetics of marine pelecypods. I. Ecological heterogeneity and evolutionary strategy at an enzyme locus. Amer. Natur., $106,47-56$.

KOEhN, R. K., Milkman, R. AND mitton, J. B. 1976, Population genetics of marine pelecypods. IV. Selection, migration and genetic differentiation in the Blue Mussel, Mytilus edulis. Evolution, 30, 2-32.

KOEHN, R. K., BAYNE, B. L., MOORE, M. N. AND SIEBENALLER, J. F. 1980. Salinity related physiological and genetic differences between populations of Mytilus edulis. Biol. J. Linn. Soc., 14, 319-334.
LEVAN, G. AND FREDGA, K. 1972. Isozyme polymorphism in three species of landsnails. Hereditas, 71, 245-252.

MCKECHNIE, S. W., EHRLICH, P. R. AND WHITE, R. R. 1975. Population genetics of Euphydryas butterflies. 1. Genetic variation and the neutrality hypothesis. Genetics, 81, 571594.

MENOZZI, P., PIAZZA, A. AND CAVALli-SFORZA, L. L. 1978 Synthetic maps of human gene frequencies in Europe. Science, 201, 786-792.

NEI, M. 1975. Molecular Population Genetics and Evolution, Elsevier, New York.

NEWKIRK, G. F. AND DOYLE, R. W. 1979. Clinal variation at an esterase locus in Littorina saxatalis and $L$. obtusata. Can. J. Genet. Cytol, 21, 505-513.

OCHMAN, H., JONES, J. S. AND SELANDER, R. K. 1983. Molecular area effects in Cepaea. Proc. Natl. Acad. Sci. USA, 80, 4189-4193.

OCHMAN, H., JONES, J. S. AND SELANDER, R. K. 1986. Data on patterns of visible and molecular polymorphism in European populations of Cepaea nemoralis and Cepaea hortensis, Evolutionary Genetics Res. Rep. 16, 1-9, Filed at the National Lending Library, Boston Spa, Yorkshire.

PIAZZA, A., MENOZZI, P. AND CAVALLI-SFORZA, L. L. 1981 a. Synthetic gene frequency maps of man and the selective effects of climate. Proc. Natl. Acad. Sci. USA, 78, 26382642.

PIAZZA, A., MENOZZI, P. AND CAVALLI-SFORZA, L. L. 1981 b. The making and testing of geographic gene frequency maps. Biometrics, 37, 635-659.

SELANDER, R. K. 1975. Stochastic factors in the genetic structure of populations. Estabrook, G. E. (ed.) In Proceedings of the Eighth International Conference on Numerical Taxonomy, W. H. Freeman, San Francisco, pp. 284-332.

SELANDER, R. K, AND OCHMAN, H. 1983. The genetic structure of populations as illustrated by molluscs. Rattazzi, M. C., Scandalios, J. G. and Whitt, G. S. (eds.) In Isozymes: Current Topics in Biological and Medical Research, Vol. 10, Genetics and Evolution, A. R. Liss, New York, pp. 93-123.

SElander, R. K. AND Whittam, T. S. 1983. Protein polymorphism and the genetic structure of populations. Nei, M. and Koehn, R. K. (eds.), In Evolution of Genes and Proteins, Sinauer Associates, Sunderland, Mass pp. 89-114.

SELANDER, R. K., SMITH, M. H., YANG, S. Y., JOHNSON, W. E. AND GENTRY, J. B. 1971. Biochemical polymorphism and systematics in the genus Peromyscus. I. Variation in the old-field mouse (Peromyscus polionotus). Studies in Genetics VI, Univ. Texas Publ. 7103, 49-90.

SLATKIN, M. 1982. Pleiotropy and parapatric speciation. Evol ution, 36, 263-270.

SNEATH, P. H. A. AND SOKAL., R. R. 1973. Numerical Taxonomy: The Principles and Practice of Numerical Classification, W. H. Freeman, San Francisco.

TUKEY, J. W. 1977. Some thoughts on clinical trials, especially problems of multiplicity. Science, 198, 679-684.

VALDEZ-FORSANS, M. 1983. Variabilité enzymatique dans les populations due mollusque Cepaea nemoralis (L.) de la vallée de l'Ariège, Pyrénées Françaises. C. R. Acad. Sci. Paris, 296, (Ser. III), 1045-1047.

VARVIO-AHO, S. L. AND PAM¥LO, P. 1982. Searching for parallel enzyme gene variation among sympatric congeners. Evol. ution, 36, 200-203.

White, M. J. D. 1978 a. Modes of Speciation, W. H. Freeman, San Francisco.

WhITE, M. J. D. 1978b. Chain processes in chromosomal speciation. Syst. Zool. 27, 285-298. 
WILliAMSON, P., CAMERON, R. A. D. AND CARTER, M.A. 1977. Population dynamics of the land snail Cepaea nemoralis (L.): a six year study. J. Anim. Ecol., 46, 181-194.
Wright, S. 1978. Evolution and the Genetics of Populations, Vol. IV, Variability Within and Among Natural Populations, University of Chicago Press, Chicago. 